\title{
$\mathrm{PHR}$ 기반 개인 맞춤형 식이·운동 관리 서비스 개발
}

\author{
정 은 영*, 정 병 희*, 윤 은 실*, 김 동 진**, 박 윤 영**, 박 동 균*
}

\section{Personalized diet and exercise management service based on PHR}

\author{
Eun-Young Jung *, Byoung-Hui Jeong *, Eun-Sil Yoon *, Dong-Jin Kim**, \\ Yoon-Young Park **, Dong-Kyun Park*

\section{요 약}

개인 맞춤형 식이·운동 콘텐츠 제공을 위해 1개 3차병원에서 제공하는 PHR(Personal Health Records)을 기반으로 건강관리 스마트폰 어플리케이션을 개발하였다. $\mathrm{PHR}$ 의 상병명에 근거하여 각 질환과의 상관관계를 적용 한 식이·운동 적합률 알고리즘을 통해 개인의 질환을 관리하기 위한 맞춤형 콘텐츠를 제공하며, 식사량과 운동량을 기록하여 섭취·소비한 칼로리를 기록하는 기능을 제공한다. 또한 사용자의 위치정보를 근거로 한, 음식점 위치 정보 및 해당 메뉴, 그에 따른 영양분석에 대한 정보를 제공하는 개인에게 적합한 콘텐츠를 이용하고 기록할 수 있는 서 비스로써, 사용자의 상태와 편의성을 고려하여 유헬스 서비스를 제공할 수 있다.

- Keywords : 개인건강기록, 건강관리, 식이, 운동, 만성질환

\begin{abstract}
We developed a Smartphone application based on PHR(Personal Health Records) provided by a tertiary hospital to provide users personalized diet, exercise contents. It uses Relevance ratio algorithm of diet and excercise being correlated with diseases listed on PHR to provide personalized contents to management of individual diseases and record the amounts of food taken and exercise along with calories consumed through exercise. Besides, developed U-Health Service
\end{abstract}

- 제 1 저자 : 정은영 • 교신저자 : 박동균

- 투고일 : 2012. 07. 20, 심사일 : 2012. 07. 31, 게재확정일 : 2012. 08. 30.

* 가천대 길병원 (Gachon University Gil Medical Center)

** 웰티즌(Welltizen)

※ 본 연구는 지식경제부 산업원천기술개발사업의 지원을 받아 수행되었음.

※ 본 연구는 지식경제부 및 정보통신산업진흥원의 대학IT연구센터 지원사업의 연구결과로 수행되었음. NIPA-2012-H0401-12-1001 
also considering users' conditions and conveniences, as a service to use contents and record suitable for the individuals who share the information on restaurants locations, their menus, and nutrition based on users' location information.

- Keywords : PHR(Personal Health Records), Health Management, Diet, Exercise, Chronic Disease

\section{I. 서 론}

최근 정보통신기술의 발전과 만성질환 관리 및 합병증예 방을 위한 수단으로 유헬스가 등장하였고, 언제 어디서나 건 강증진콘텐츠를 제공하고 건강관리 서비스를 제공하기 위한 연구들이 활발히 진행 중이다[1].

유헬스 개념의 확대로 다수의 사용자에게 획일적인 서비스 가 아닌 개인 맞춤형 건강관리 서비스를 제공하기 위한 다양 한 콘텐츠들이 제공되고 있지만, 맞춤형 서비스에는 여러 가 지 한계가 있고, 맞춤형을 만족시킬 수 있는 정보의 범위와 입력에 한계를 가지고 있다. 현재 제공되고 있는 많은 서비스 는 사용자가 자신의 상태와 정보를 직접 입력하여야 하고, 이 를 기반으로 프로그램에 의해 맞춤형 서비스를 제공한다. 하 지만 환자가 작성하는 정보의 범위는 한계가 있으며, 정확한 정보의 입력이 검증 되지 않아 적정한 콘텐츠와 서비스가 적 용되기 어려운 현실에 있다. 또한 건강관리를 위한 서비스를 제공하기 위해 웹기반, IPTV기반, 홈모니터링 등 많은 유헬 스 서비스들이 제공되고 있지만 사용자의 절실한 의지와 동기 가 부여되지 않는 한 지속적인 건강관리가 어렵다.

본 연구에서는 PHR(Personal Health Records)을 직접 식이·운동 콘텐츠 제공 서비스 어플리케이션과 연동하여 병원 정보를 근거로 사용자에게 맞춤형 서비스를 제공하고자 한다. 또한 신속하게 정보를 제공받을 수 있고, 언제 어디서나 이용 가능한 스마트폰이 최근 유헬스 분야 디바이스로 부상하고 있 기 때문에[2][3] 스마트폰을 활용하여 병원 정보를 연동한 개인 맞춤형 식이·운동 콘텐츠 제공 서비스를 개발하였다.

\section{II. 관련 연구}

\section{1. 질환자를 위한 식이·운동 추천}

식단 추천 서비스란 개인의 영양섭취 상태를 분석하여 영 양적 불균형 상태를 완화시키는데 도움이 될 음식들을 추천하 는 서비스이다[4]. 기존의 식단 추천 서비스의 대표적인 예로
병원서비스, 웹, IPTV로 제공하는 서비스이다.

먼저, 전문 의료인의 일반적인 식단 제약사항을 고려한 방 법은, 의사가 환자의 건강 상태를 판단하여 피해야 할 식단 관련 제약 사항을 처방한다. 이는 사용자 개개인의 음식 선호 도를 고려하지 않고, 질병의 심각성을 고려하지 않은, 수동적 인 식단 처방 방법으로 환자의 요구를 능동적으로 대처할 수 없다[5]. 웹으로 서비스를 제공하는 (주)웰티즌은 사용자의 기 본 정보를 자가 입력 후, 건강상태에 대한 설문을 입력하면 그에 맞는 식이·운동 처방이 일주일 단위로 제공된다. 혈압, 혈 당 관리뿐만 아니라 체중조절과 근육강화를 위한 식이·운동 처방 도 제공한다. 모바일로도 서비스를 제공하는데, 스마트폰 어플리 케이션 방식이 아닌 인터넷 접속 방식으로 이용 가능하다[6].

IPTV를 이용한 식이·운동 추천 서비스로는 KT QOOK에 서 제공하는 Dreamcare TV서비스로 사용자에게 IPTV를 통해 체중관리, 질병관리, 질병정보 검색, 운동처방 등의 서 비스 제공한다[7]. 이상의 웹, IPTV서비스는 집, 실내에서 사용해야 하는 공간적 제한의 한계로 인해 바로바로 사용하기 힘든 가용성의 문제가 있다.

당뇨병 환자를 위한 스마트폰 기반 식단관리 프로그램에 대한 연구에서는 레시피와 함께 계절, 날씨, 선호도를 반영하 여 식단을 추천하며, 사용자의 선호도를 반영하기 위하여 대 체식단을 제시하였다[8]. 고령자를 위한 운동처방 서비스에 대해 연구에서는 기계학습으로 체력상태의 연령과 비만도를 유형별로 분류하여 운동처방을 한다. 처방된 운동대로 고령자 가 운동을 하는 동안 심박수, GPS 정보 등이 저장되어 정보 를 확인하고 동기를 부여받는다[5].

여러 질환자들을 대상으로 식이·운동 추천 서비스가 연구 중에 있으나, 본 연구에서는 하나의 질환이 아닌 대표적인 만 성질환을 포함한 11 가지 질환에 따라 식이·운동을 추천하고 그에 따른 적합률을 제공하여 사용자가 스스로 근거기반 서비 스 이용에 흥미를 느낄 수 있도록 하였다.

\section{2. 스마트폰 기반 유헬스 프로그램}

최근 스마트폰의 사용자수가 2,500 만 명을 넘어감에 따라 스마트폰 어플리케이션으로 제공하는 서비스의 종류와 수가 다양해졌다. 유헬스 서비스도 마찬가지로 운동관리, 칼로리 
관리, 혈압, 혈당 관리 어플리케이션이 많이 개발되고 있다. 대표적인 운동관리 서비스로 나이키, 아디다스의 마이코치 등 이 있는데, 걷기, 달리기 등의 운동을 할 때의 시간, 거리, 속 도, 소모 칼로리 등을 확인할 수 있다[9][10].

경희대학교 병원에서 개발한 '당뇨병 수첩'은 사용자의 정 보를 입력해 하루하루 혈당을 입력하고 그래프를 통해 본인의 상태를 확인할 수 있다. 또한 프래밍험 스코어(Framingham score)를 이용하여 심혈관질환 발생 위험도를 계산할 수 있는 기능도 포함되어 있다[11].

경기도, 질병관리본부, $\mathrm{KT}$, 퀄컴이 협력하여 제공 중인 'Q-Care 고혈압 당뇨병 자가 관리 서비스' 어플리케이션은 현재 경기도 광명시에서 시범사업을 시행 중인 서비스이다. 시범사업중인 고혈압, 당뇨병 환자는 혈당, 혈압, 운동, 영양 관리를 할 수 있으며 사용자의 데이터가 웹으로 의사에게 전 달되어 맞춤형 상담 및 진료를 할 수 있다[12].

국외의 연구에도 개인 의료 정보를 수집하여 건강관리를 하는 모바일 어플리케이션들이 다양하다. Minolasoft에서 개 발한 'AidHealth'[13] 스마트폰 어플리케이션은 사용자의 체중, 혈압, 체온, 칼로리 섭취, 소비량, 관리하고 싶은 모든 수치들을 기록하여 관리하는 기능을 제공한다. 또한 가족의 건강수치도 관리할 수 있다. 기록한 수치들은 그래프로 목표 수치와 비교하여 나타낸다. Hyrax Inc.에서 개발한 'My Medical'[14] 어플리케이션은 기본적인 건강정보, 약물, 알 레르기, 면역, 진단기록 등의 개인건강정보를 정보의 보안을 위해 서버에 저장하지 않고 이용 중인 단말기에 저장한다. 단말 기는 스마트폰을 비롯하여 패드와 노트북도 지원한다. 가족의 정보도 저장할 수 있으며 응급연락처를 저장해두어 위급상황에 대처할 수 있도록 한다. 또한 담당 의사의 정보를 기록할 수 있 고, 진료 예약 일정 이 달력으로 자동 입력되는 기능이 있다.

Polka Networks에서 제공하는 'Polka Health'[15]는 웹의 기록과 스마트폰의 기록을 언제 어디서나 연동하여 사용 할 수 있는 어플리케이션이다. 자신의 건강정보를 의료진, 가 족, 전문가들로 이루어진 '팀'과 공유할 수 있다. 상황별 자신 의 상태를 별 다섯 개로 나타내어 비공개, 팀공개, 트위터에 포스팅하는 기능이 있다.

스마트폰은 장소적인 한계를 뛰어넘어 언제 어디서나 사용 가능하고, 내장되어 있는 카메라와 센서를 이용할 수 있기 때 문에 유헬스 서비스를 더욱 효과적으로 사용할 수 있다.

식이·운동은 질환을 관리하기 위해 실생활에서 가장 중요 하고 실행하기 쉬운 건강관리 요소이다. 하지만 환자의 의지 와 동기부여가 되지 않으면 지속적으로 관리하기 어려운 항목 이다. 이에 스마트폰을 활용하면 자신의 기록을 피드백 하여
동기부여를 할 수 있으며 알림 서비스로 지속적인 사용을 기 대할 수 있다.

\section{PHR (Personal Health Record)}

$\mathrm{PHR}$ 은 1978년부터 사용되기 시작한 용어인데[16], 현 재 Personally Controlled Health Record, Personal Medical Record, Electronic Health Record 등 다양한 용어와 뒤섞여 사용되고 있다. PHR에 대한 정의는 여러 기 관에서 발표하고 있는데, 그 중 The Healthcare Information and Management Systems Society (HIMSS)에서 2007 년 공식적으로 발표한 자료에 의하면[17]. "PHR은 개인이 본인이나 가족의 일생 동안의 모든 건강 정보에 대해서 안전 하게 보관하면서 관리하는 기능을 제공하는 도구" 라고 정의 하였다. PHR은 의료서비스 소비자에게 다양한 건강정보를 제공하고, 그들의 건강을 스스로 통제 및 관리할 수 있는 수 단을 제공하며, 의료전달 체계에 보다 능동적으로 개입하고 밎 의사결정 과정에 참여할 수 있는 수단을 제공한다. 이러한 $\mathrm{PHR}$ 은 전통적인 소비자와 의료 전달체계 내의 각 이해관계 자 간의 역할 및 관계가 보다 소비자 중심적으로 변화하도록 유도하고 있으며 이에 따라 각 이해관계자는 새로운 형태의 효익을 얻을 수 있다. PHR이 구축되어 활용될 경우 다양한 장점들이 있는데[18], 신수용 등의 연구에서는 첫 번째는 완 전한 건강기록을 할 수 있다는 것이다. 자신의 일생 동안의 의무기록을 한 곳에서 확인할 수 있기 때문에 건강관리가 용 이해 진다. 두 번째로 유비쿼터스 헬스케어가 가능해진다. 가 정용 의료기기에서 측정하여 저장되는 데이터를 $\mathrm{PHR}$ 에 저장

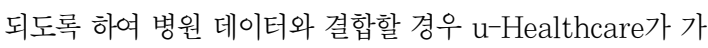
능해진다. 또한 의료진의 적극적인 참여로 원격 진료도 가능 해 진다. 세 번째로 환자 교육 및 관리가 활발해질 수 있다. 국내에서 네이버와 의사협회가 공동으로 네이버 지식in에 의 료상담답변을 통해 의학 정보를 제공해오고 있다. PHR을 활 용한다면 환자에게 맞춤화된 정보를 제공할 수 있을 것이다. 마지막으로 병원간 진료 정보 교류가 확대될 것이다. 기존 병 원간 진료 정보 교류 방법은 의무기록 사본을 전달하는 방식 이었다. 하지만 PHR을 이용한다면 환자의 동의를 받아서 의 사가 언제든지 필요한 정보에 접근할 수 있게 된다고 하고 있 다. 이상의 장점들을 제공하는 $\mathrm{PHR}$ 의 기능은 정보 수집, 공 유, 교환, 자가 관리 등으로 요약할 수 있다. 


\section{PHR 기반 맞춤형 식이·운동 관리 시스템}

\section{1. $\mathrm{PHR}$ 정보 연동 시스템}

본 연구에서 대상으로 하는 질환은 총 11 가지로 표 1 과 같이 해당질환명은 ICD(International Statistical Classification of Diseases and Related Health Problems)-10 code를 매핑한 PHR 상병명을 연동하였다. 11 가지의 질환 정보를 기 반으로 애플리케이션 사용자의 보유 질환에 따른 식이·운동 콘텐츠를 제공한다.

표 1. 상병명과 ICD-10 code 매핑 정보

Table 1. Diagnosis mapping with ICD-10 code

\begin{tabular}{|c|c|}
\hline 상병명 & ICD-10 Code \\
\hline 우울증 & $\mathrm{F} 32^{*}$ \\
\hline 고혈압 & $\mathrm{I10*}$ \\
\hline 당뇨 & $\mathrm{E} 10^{*}, \mathrm{E} 11^{*}$ \\
\hline 비만 & $\mathrm{E} 66^{*}$ \\
\hline 고지혈증 & $\mathrm{E} 785$ \\
\hline 위암 & $\mathrm{C} 16^{*}$ \\
\hline 간암 & $\mathrm{C} 22^{*}$ \\
\hline 폐암 & $\mathrm{C} 34^{*}$ \\
\hline 대장암 & $\mathrm{C} 18^{*}$ \\
\hline 유방암 & $\mathrm{C} 50^{*}$ \\
\hline 자궁경부암 & $\mathrm{C} 53^{*}, \mathrm{C} 54^{*}, \mathrm{C} 55^{*}$ \\
\hline
\end{tabular}

2. 사용자 질환 정보에 따른 식이·운동 적합률 도출 시스템

\section{1 식이 적합률}

본 질환별 식이 적합률은 개발 이전에 다년간의 질환별 식 이요법과 관련된 자료들을 조사하여 그 결과들을 활용하였으 며, 식이 적합률 도출을 위한 구성은 임상영양학을 기초로 하 여 질환별 발병기전, 발생요인 및 식이요법에 영향을 미치는 영양성분들의 연구결과들을 토대로 하나의 음식이 각 질환에 필요한 영양소가 얼마나 적합한지를 나타내는 적합률 $(\%)$ 알 고리즘 형태로 구현 하였다. 또한 알고리즘에 적용되는 임상
학적 수치는 전문의에 판단 하에 적용함을 전제로 하며, 질환 별 적합률은 우울증 외 총 10 가지정도로 구현하였다.

\section{1) 식이 적합률 산출과정}

질환별 음식 적합률 도출을 위한 프로그램 개발과정은 그 림. 1흐름과 같다. 우선 질환별 음식 적합률 사용자의 PHR 정 보는 의료기관으로부터 제공받아 (주)웰티즌이 보유한 Restaurant DB와 Diet DB로 부터 사용자가 선택한 메뉴 의 메뉴리스트, 선택음식의 적합성, 1 인 분량의 칼로리와 영 양정보 값을 산출하고, 검색에 따른 산출 값은 사용자에 의해 선택항목이 백분율 $(\%)$ 형태로 검색 되도록 구성하였다.

적합률 도출을 위한 기본 단계는 음식에 함유된 영양성분 을 토대로 분석하였으며, 분석된 영양 성분은 (사)한국영양학 회 에서 발간한 〈한국인영양섭취기준 2010년 (DRIs: Dietary Reference Intakes for Koreans)> 자료에 따라 상관관계를 고려하고, 질환에 따른 특이성을 고려 후 질환별 식이 적합률로 산출하였다.

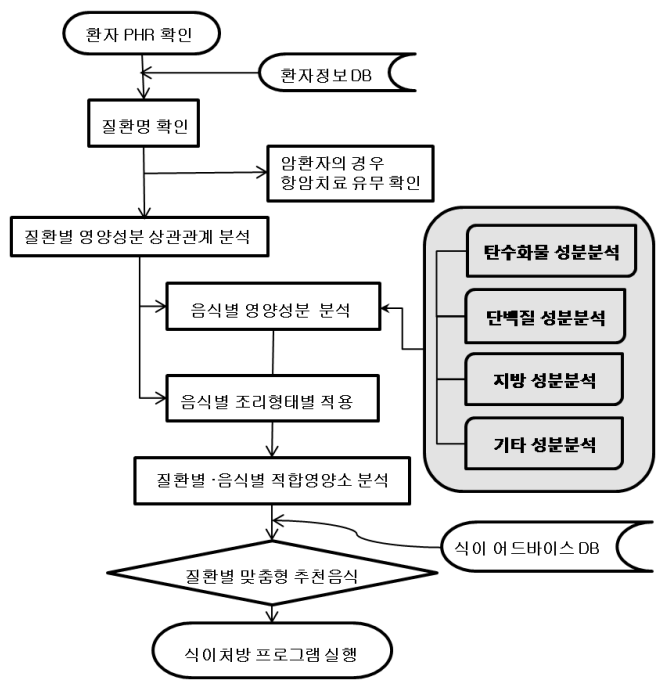

그림 1. 질환별 식이 적합률 도출 순서도 Flow chart Fig. 1. Diseases related dietry relevance ratio flow chart

\section{2) 식이 적합률 적용영양소}

질환별 적합률 산출을 위한 산출방법은 프로그램에서 공통 적으로 적용되는 영양소 성분인 탄소화물, 단백질, 지방(포화 지방산, 불포화지방산), 트립토판, 콜레스테롤, 비타민 $\mathrm{A}$, 비 타민B. 비타민C, 비타민E, 셀레늄 $(\mathrm{Se})$, 마그네슘 $(\mathrm{Mg})$, 칼 슘 $(\mathrm{Ca})$, 나트륨 $(\mathrm{Na})$, 식이섬유소 등 16 가지 적용영양소를 
선택하여 한국인 1 일 권장량을 기준(\%RDA) 값을 고려하여 질환에 따른 적용영양소 수치를 적용하였고, 각 질환별 영양 소 적용비율은 음식별 적합성을 고려하여 산출하였다.

각 질환의 적합률을 구성하는 영양 성분은 표 2 로 제시하였다.

표 2. 질환별 적합률 산출을 위한 적용 영양소

Table 2. Nutrients information for diseases related dietry relevance ratio

\begin{tabular}{|c|c|}
\hline 질환 & 적용 영양소 \\
\hline 우울증 & $\begin{array}{l}\text { 탄수화물:단백질:지방, 트립토판, 포화지방산, } \\
\text { 콜레스테롤, 비타민B, 셀레늄(Se), 마그네슘(Mg), } \\
\text { 칼슘(Ca) }\end{array}$ \\
\hline 고혈압 & $\begin{array}{l}\text { 탄수화물:단백질:지방, 나트륨 }(\mathrm{Na}) \text {, 식이섬유소, } \\
\text { 포화지방산, 칼륨 }(\mathrm{K}) \text { 마그네슘 }(\mathrm{Mg}) \text {, 칼슘 }(\mathrm{Ca})\end{array}$ \\
\hline 당뇨 & 탄수화물:단백질:지방, 식이섬유소, 포화지방산 \\
\hline 비만 & 탄수화물:단백질:지방, 식이섬유소 \\
\hline $\begin{array}{l}\text { 고지혈 } \\
\text { 증 }\end{array}$ & $\begin{array}{l}\text { 탄수화물:단백질:지방, 포화지방산, 불포화지방산, } \\
\text { 섬유소, 비타민C, 비타민E, 칼슘(Ca) }\end{array}$ \\
\hline 위암 & $\begin{array}{l}\text { 탄수화물:단백질:지방, 나트륨 }(\mathrm{Na}) \text {, 불포화지방산, } \\
\text { 비타민C, 비타민E }\end{array}$ \\
\hline 폐암 & 탄수화물:단백질:지방, 비타민 A, 비타민C, 비타민E \\
\hline 간암 & $\begin{array}{l}\text { 탄수화물:단백질:지방, 단백질, 비타민 A, 비타민C, } \\
\text { 비타민E }\end{array}$ \\
\hline $\begin{array}{c}\text { 자궁경 } \\
\text { 부암 }\end{array}$ & 탄수화물:단백질:지방, 비타민 $\mathrm{A}$, 비타민C, 비타민E \\
\hline 유방암 & 탄수화물:단백질:지방, 비타민 $\mathrm{A}$, 비타민C \\
\hline 대장암 & 탄수화물:단백질:지방, 섬유소, 유당, 비타민 C \\
\hline
\end{tabular}

\section{3) 식이 적합률 산출방법 (우울증 제시)}

일반적으로 질환에 따른 영양소의 요구량은 질환의 종류, 약물과 영양소와의 상호작용, 여러 가지 영양소 간의 상호작 용 등을 고려해야 한다. 본 연구에서는 질환별 선택음식의 적 합률 산출을 위해 1 일 한국인 영양섭취량 및 영양권장량 (RDA) 등을 기준으로 질환에 따른 섭취영양소별 적용수치를 가감하여 섭취영양소 적정수치를 급간(class interval)별 점 수로 분류하여 점수합산의 값을 계산식에 적용하였다.

총 11 가지의 질환 중 우울증(Depression)의 적합률 과정 을 설명하면, 최근 우울증의 대한 연구결과에 따르면 식이 및 영양소가 신경전달물질의 생산 변화를 유발하여, 신경학 및
심리학적으로 병을 치료할 수 있다고 설명한다 [19][20][21][22].

특정 물질이 발휘하는 항우울 효과에 관한 해명은 아직 불 분명한 것이지만 어떤 영양소들은 약물과 상호작용하여 치료 에 효과를 내는 경우도 있다[23]. 이러한 연구 이론들을 토대 로 우울증 적합률 산출 시 적용하는 영양소는 3 대 영양소의 비율(탄수화물, 단백질, 지방) 외 트립토판(세로토닌의 전구 물질), 포화지방산, 콜레스테롤 등으로 해당 영양성분을 포함 하는 음식이 우울증과 얼마큼의 적합률을 가지고 있는지 계산 식을 구성하여 산출하였으며, 그림 2 와 같다.

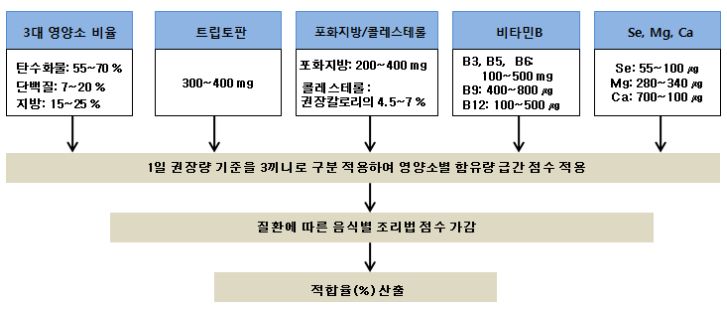

그림 2. 우울증 식이 알고리즘

Fig. 2. Algorithm of depression diet

\section{우울증과 식이와의 관계}

우울증은 식이장애, 즉 먹는 것의 장애를 가져올 수도 있 고, 식이장애가 우울증에 기여할 수도 있다[24]. 우울증 환자 의 행동 특징을 연구한 결과를 살펴보면[25], 감정적 측면과 신체적 측면의 불만 요인으로 인한 비정상적인 행동이 나타나 며, 그 중 식행동과 관련된 식이장애는 불량한 식습관을 형성 할 수 있으며, 결국 불균형을 초래할 수 있다.

\section{우울증 적용 영양소 설정기준}

본 연구에서는 특정 영양소가 우울, 불안, 행동에 영향을 끼칠 수 있음을 전제로 하며, 정신기능에 있어 일부 영양소가 우울증 개선에 효과를 가져다 줄 수 있다는 선행 연구들을 토 대로 구성하였으며, 적용영양소 설정기준은 한국영양학회에 서 제시한 한국인영양섭취기준(KDRIs)[26], 임상영양관리 지침서 [27], 우울증 영양치료[28][29],

www.vitamedics.co.kr [30], 등의 선행 연구내용을 참고 하여 설정영양소를 기준치화 하여 알고리즘 방안을 제시하였다.

\section{1) 3 대 영양소 섭취비율}

우울증은 식품의 선택 및 식이 섭취에 변화를 초래하여 식 옥부진 및 대식증을 초래할 수 있으므로, 정상적인 기능과 건 강을 유지하기 위하여 필요한 영양소 수준으로 성인기준(19 
세 이상) 권장비율을 탄수화물 55 70\%, 단백질 7 20\%, 지방 $15 \sim 25 \%$ 를 기준으로 적용하였다.

\section{2) 트립토판(세로토닌 전구물질)}

뇌 안에 세로토닌 생성은 트립토판의 공급과 관계가 있으 며, 실험을 통해 트립토판이 결여된 음식을 공급하게 되면 세 로토닌은 저하되고, 적당한 조건에서 식사 섭취를 증가시키면 전구체들은 신경전달 물질의 생성을 촉진시킬 수 있고 보고되 고 있다.〔31]이에 트립토판을 우울증 적합률 적용영양소로 성인기준 권장비율은 1일 300 4000mg 으로 적용하였다.

\section{3) 포화지방산 및 콜레스테롤}

콜레스테롤 강하제는 우울증을 발생시키기도 하며, 또 콜 레스테롤이 줄면 스트레스에 대한 내성도 저하되어 증상이 악 화되기 쉽다[32]. 또한 스페인 라스 팔마스 데 그란 카나리아 대학과 나바라 대학 공동연구팀의 조사에 따르면 트랜스지방 과 동물성 지방인 포화지방 섭취량이 많은 사람이 적게 섭취 한 사람에 비해 우울증 발생률이 평균 $48 \%$ 높은 결과에 따라 콜레스테롤과 포화지방산을 우울증 적합률 적용영양소로 선 정하였으며, 임상영양관리 지침서 2010년을 참고하여 적용 비율은 콜레스테롤은 성인기준 1일 200 400mg으로, 포화 지방산은 성인기준 1 일 권장칼로리(남자 $2600 \mathrm{kcal}$, 여자 $2100 \mathrm{kcal})$ 평균값의 $4.5 \sim 7 \%$ 로 적용하였다[33].

\section{4) 비타민B (B3, B5, B6, B9, B12)}

우울증에 있어 비타민B 복합체 요소들은 뇌 기능에 주요 물질로서 세로토난, 토파민과 같은 신경전달물질의 합성에 필 수적 작용을 하며, 세로토닌 합성을 상승시키기도 한다. 또한 기분전환 및 우울증에도 크게 기여하는 영양소로 작용한다 [34][35]. 이에 비타민B 복합체를 5가지로 구분하여 적용하 였으며, 적용기준은 성인기준 1일 권장비율 $\mathrm{B} 3$ (niacin), B5(pantothenic acid), B6(pyridoxine)은 100 500mg, B9(folic acid) 400 800 $\mu \mathrm{g}, \mathrm{B} 12$ (cobalamin) 100 500 $\mu \mathrm{g}$ 로 적용하였다[36].

\section{5) 셀레늄(Se), 마그네슘(Mg), 칼슘(Ca)}

미량 원소인 셀레늄은 대표적인 항산화 영양소로 셀레늄의 투여에 따른 뇌조직의 항산화력이 증강 효과를 가지는 것으로 선행연구결과 확인되었으며[37], 마그네슘은 신경과 근육의 흥분성을 정상화하는데 있어 칼슘과 협동적 또는 길항적으로 작용을 하며, 세로토닌을 만드는데 도움을 주며 혈중 세로토 닌 증가시켜 우울증에 효능을 가진다[38]. 또한 칼슘의 경우
많은 선행연구 결과만으로도 칼슘 제제의 섭취가 우울 및 불 안 성향을 개선시키며, 주관적 신체 상태를 호전시켜 우울증 을 완화시켰다고 보고되며[38], 칼슘이 부족하면 뇌의 활동 이 저하되고 초조하거나 우울해지고 사고력이 저하될 수 있다 고 보고된다. 이러한 선행 연구내용들을 토대로 적용영양소로 선정하였으며, 적용기준은 성인기준 1 일 권장비율 셀레늄 (Se) $55 \sim 100 \mu \mathrm{g}$, 마그네슘 $(\mathrm{Mg}) \quad 280 \sim 340 \mu \mathrm{g}$, 칼슘 $(\mathrm{Ca})$ 700 1000mg으로 적용하였다.

표 3. 우울증 적용영양소 이론적 근거 및 적용비율

Table 3. Depression, rationale and application rates of nutrients applied

\begin{tabular}{|c|c|c|}
\hline 적용영양소 & 이론적 근거 & 적용비율 \\
\hline $\begin{array}{l}\text { 3대 영양소 섭취비율 } \\
\text { (탄수화물:단백질:지방) }\end{array}$ & $\begin{array}{c}\text { 정신의학적으로 극단적인 } \\
\text { 식이 행동 문제의 개선을 } \\
\text { 기준으로 하며, 보통 3대 } \\
\text { 영양소 섭취비율 } \\
\text { 적절하게 섭취 권장함 }\end{array}$ & $50 \%$ \\
\hline 트립토판 & $\begin{array}{c}\text { 세로토닌의 } \\
\text { 전구체물질이며, } \\
\text { 세로토닌 생성촉진 }\end{array}$ & $10 \%$ \\
\hline 포화지방산 & \multirow{2}{*}{ 우울증 발생비율 증가 } & \multirow{2}{*}{$10 \%$} \\
\hline 콜레스테롤 & & \\
\hline 비타민B & $\begin{array}{c}\text { 스트레스 완화, } \\
\text { 세로토닌 생성 촉진, } \\
\text { 편안상태 유지 }\end{array}$ & $10 \%$ \\
\hline 셀레늄(Se) & 항 스트레스 비타민 & \multirow{3}{*}{$10 \%$} \\
\hline 마그네슘(Mg) & $\begin{array}{c}\text { 칼슘과 균형, 근육이완 } \\
\text { 작용 }\end{array}$ & \\
\hline 칼슘(Ca) & 신경안정작용 & \\
\hline
\end{tabular}

그러나 본 연구에서 제시한 적용영양소 기준안과 분량의 기준단위에 대한 타당성을 검증하기 위하여 더 많은 식품들 대한 검토가 필요 할 것이다.

\section{2 운동 적합률 도출}

본 연구에서 질환별 운동 적합률 도출은 임상운동처방을 기초로 하여 운동종목에 대한 정보와 사용목적 기반을 두고, 사용자 PHR 정보, 운동처방 정보, 운동종목 및 동영상 정보 등으로 알고리즘을 구성하였으며 적용 시 전문의 판단 하에 적용함을 전제로 하였다. 운동 적합률 도출을 위한 flow chart는 그림 3과 같다. 


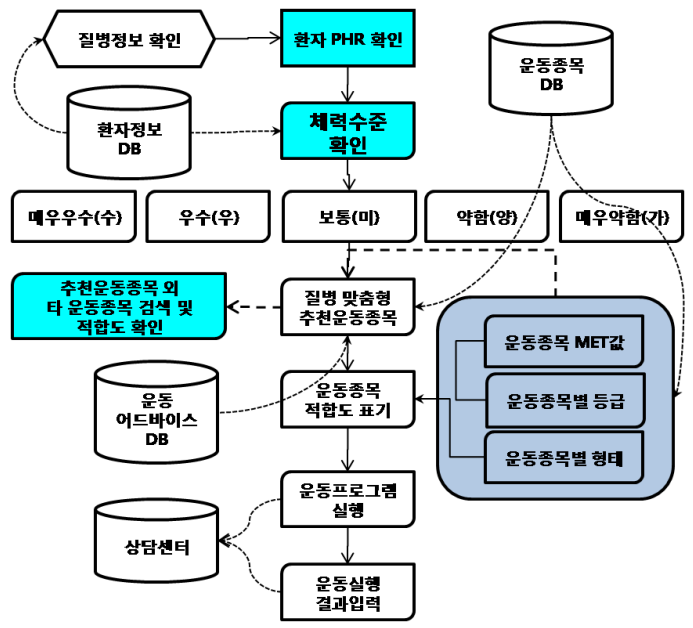

그림 3. 운동처방 순서도

Fig. 3. Flow chart of exercise prescription

일반적으로, 개인의 심폐체력수준(cardiopulmonary fitness level)은 심혈관 기능을 평가하고 성인병을 예측할 수 있는 중 요인자이며, 건강관련 체력의 중요한 구성요소로써 보통 최대 산소섭취량(VO2max)으로 평가하고 있으며, Astrand(1954)의 보고에 의하면 사람의 최대운동능력은 호흡순환기능 등의 산 소운반시스템에 따라 결정되는데, 이것은 최대산소섭취량을 직접적으로 측정하여 능력 정도를 구할 수 있다. 하지만 시간 적, 공간적 및 비용발생의 문제 등에 따라 체력수준 및 맞춤 운동을 제공하는 것이 번거롭기 때문에 간편하게 간접적인 방 법으로 추정하는 연구들이 꾸준히 진행되었다. 관련된 연구들 에서 제시하고 있는 간접추정 변인에는 대상자의 신체적 특 성, 신체구성과 신체활동 정도, 그리고 피험자의 운동습관 및 질병상태 및 정도 등이 포함되어 있다(Faulkner et al., 2007; Wier et al., 2006; Jackson et al. 1990). 그러므 로 질환대상별 운동처방 및 운동적합률 제공은 심폐체력수준, 신장, 체중, 신체질량지수, 운동종류 및 대사량(MET's), 운 동강도, 운동유형 등의 7 개 변인으로 추정해볼 수 있다.

이에 본 연구에서 질환별 운동 적합률에 제공은 위에서 언 급된 7개 변인을 각각의 중점도와 난이도로 구분해서 통합적 으로는 \%화하여 제공하였다. 그리고 관련정보는 (주)웰티즌의 운동처방 관련 $\mathrm{DB}$ 와 운동동영상 $\mathrm{DB}$ 에서 사용자가 선택한 메뉴의 운동리스트, 체력수준 정도, 선택운동과의 적합성 정 도, 운동시간에 따른 소모 칼로리를 산출하고, 검색에 따른 산출 값을 백분율 $(\%)$ 형태로 검색되도록 하였다. 또한 질환 에 따른 운동 적합률 도출을 위한 기본 단계는 Darren(2006)이 운동참여 전 신체상태 확인과 운동종목에 따른 MET 및 분류
기준을 적용하여 맞춤운동처방 적합률 시스템으로 구성하였 다[39]. 세부적으로는 질환별로 추천되는 운동을 분류하고 각 운동종목에 따른 $\mathrm{MET}$ (대사당량) 값과 운동형태, 운동종목 의 난이도를 분석하여 데이터화하였다. 그리고 질환과 운동종 목과의 상관관계를 산출조건식에 적용하여 각 질환별로 운동 종목의 적합률이 나타나도록 하였다. 또한 운동실행 내용이 입력 및 저장되면 모니터링 하여, 향후 지속적인 운동 상담이 가능하도록 하였다.

한편, 적합률 도출 알고리즘이 반영되는 것은 개인의 기본 적인 사항으로 데이터가 반복하여 발생되지 않는 정보이다. 그러므로 사용자 PHR 정보와 맞춤운동처방 정보 히스토리 사이에는 일 대 다의 관계가 성립되게 구성하였고, 질병정보 히스토리와 운동처방 히스토리 사이에도 역시 연관 관계가 있 기 때문에, 일 대 다의 관계가 성립하도록 하였다.

\section{IV. 시스템 구현}

\section{1. 시스템 구성도}

시스템 구성도는 그림 4 와 같이 PHR 서비스에 가입하고 애플리케이션을 이용하면 질병정보에 의해 해당되는 콘텐츠 를 서비스 하는데, 질환에 맞는 음식 및 운동 추천 뿐 아니라 음식과 운동과의 적합률을 고려하여 개인 맞춤형 콘텐츠를 제 공한다.

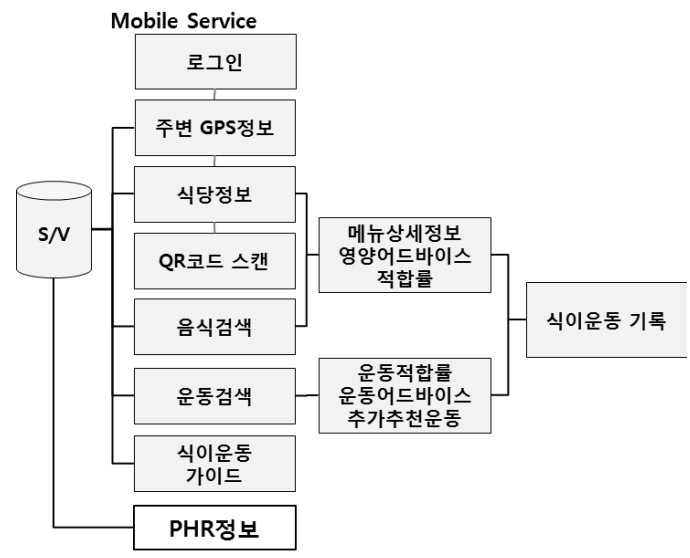

그림 4. 시스템 구성도

Fig. 4. System Components 


\section{2. 개발 환경}

본 서비스는 스마트폰 어플리케이션으로, 안드로이드 운영 체제 기반으로 개발되었다. GPS 기반으로 제공되는 식당 정 보와 식당 내 음식 영양 분석 정보는 지자체의 영양 표시 사 업에서 제공하는 $\mathrm{DB}$ 를 활용하였다. 일반적인 식이·운동 콘텐 츠는 (주)웰티즌에서 제공하는 $\mathrm{DB}$ 를 활용하여 시스템을 구축 하였다.

\section{3. 서비스화면}

그림 5 는 어플리케이션 실행시의 메인화면이다. 개발된 프 로그램에는 사용자의 질환정보에 따른 식이·운동 콘텐츠 제공 뿐만 아니라 주변GPS 정보를 기반으로 내 주위의 추천 식당 을 알려주고 식당 내 음식정보, 영양 분석 정보를 제공한다.

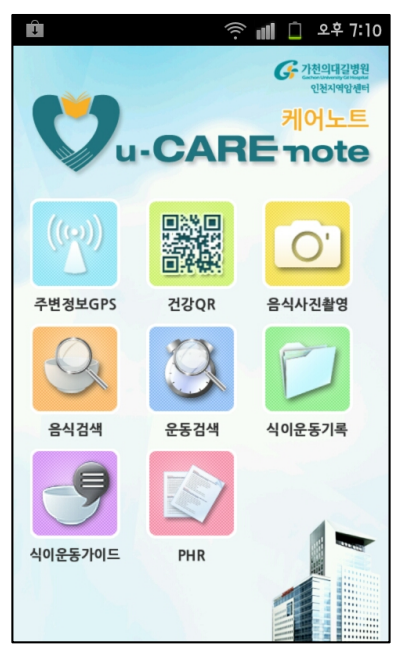

그림 5. 서비스 메인화면

Fig. 5. Main screen

\subsection{PHR연동}

사용자에게 유용하고 적합한 콘텐츠를 제공받기 위해서는 개인정보를 수집하여야 하는데, 이를 위하여 사용자의 PHR 정보를 연동하였다. 그림 6 은 사용자의 PHR정보가 연동되어 단말기에 제공되는 화면이다. 기본적인 개인의료정보와 병력, 활력징후, 암 환자인 경우 항암치료 관련 정보 등이 제공된다.

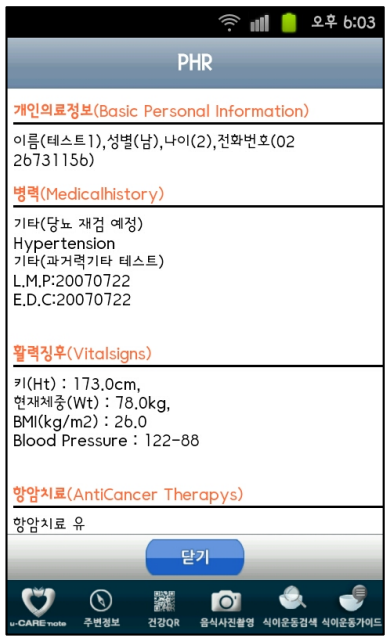

그림 6. PHR 정보 연동

Fig. 6. linked PHR information

\section{2 식이\&운동 검색}

사용자가 섭취할 예정이거나 음식의 정보를 알고 싶을 경 우 음식검색을 통해 칼로리와 영양정보, 적합률 등을 확인한 다. 그림 7 과 같이 원하는 음식의 이름을 검색하여 적합성을 확인한다. 만약 섭취한 경우 ‘섭취' 버튼을 눌러 식사기록에 추가하여 식사이력 관리가 가능해진다. 운동검색도 마찬가지 로 운동 종류에 따른 사용자 별 적합성이 계산되어 그림 8 과 같이 제공된다. 신체 부위별로 검색할 수 있고 실행 시간에 따른 칼로리 소모와 운동 방법 등이 제공되고 있어 적절한 운 동 서비스를 받을 수 있다.

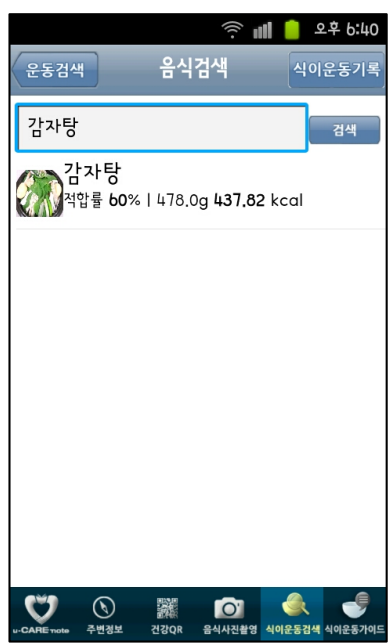

그림 7. 음식 검색

Fig. 7. Food retrieval 


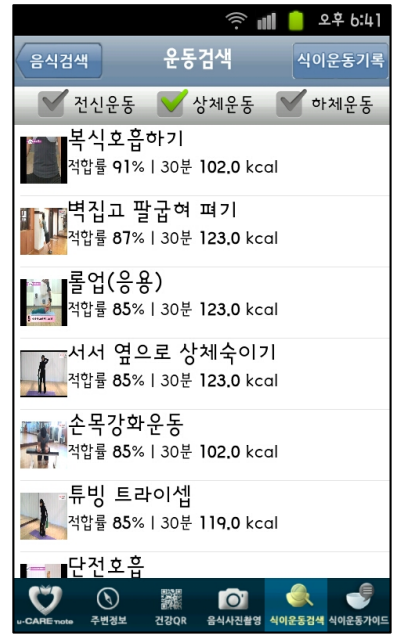

그림 8. 운동 검색

Fig. 8. Excercise retrieval

\section{3 식이\&운동 기록}

식사이력에서 매 식사와 하루에 필요한 칼로리와 영양소를 관리할 수 있는데, 그림 9와 같이 섭취한 음식의 양을 기록하 면 그림 10 과 같이 하루 단위로 데이터가 누적되어 총 섭취 칼로리를 계산할 수 있게 된다. 섭취한 음식의 양은 그릇, 접 시, 대접, 뚝배기, 국자 등의 단위로 기록할 수 있게 구현하였 다. 운동이력에서도 실제로 운동한 시간을 입력하면 그림 11 , 12 와 같이 그에 따른 소비 칼로리가 입력되어 하루 동안의 소 비 칼로리 정보가 제공된다.

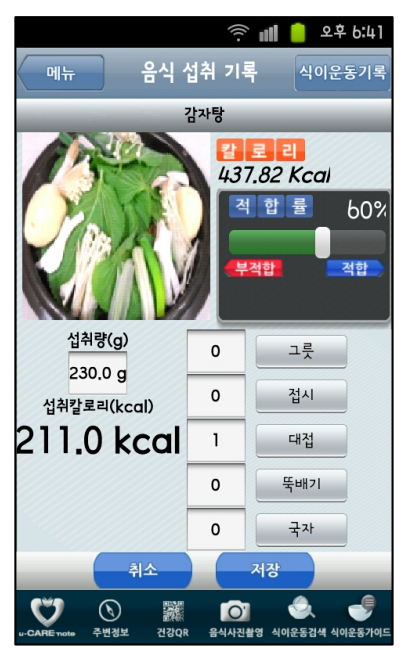

그림 9. 음식 섭취 기록

Fig. 9. Food ingestion records

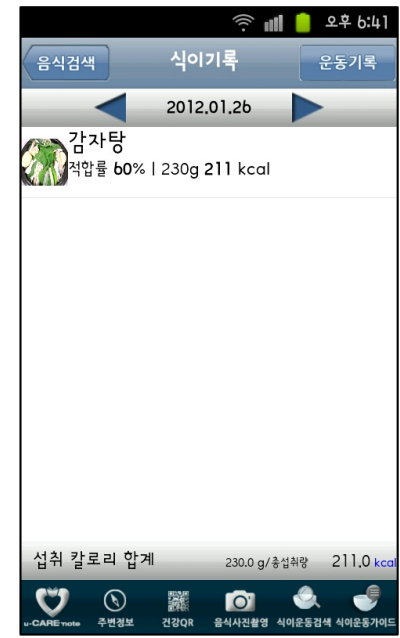

그림 10. 식이기록

Fig. 10. Diet records

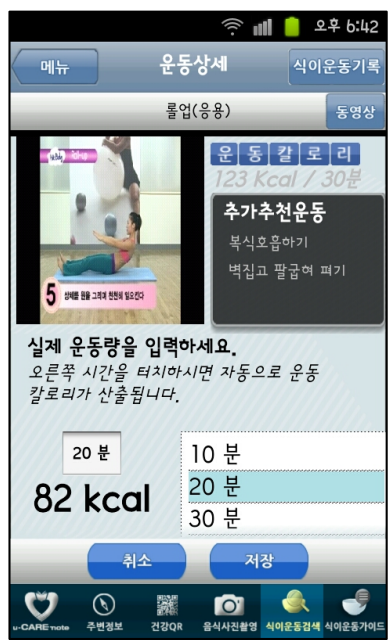

그림 11. 운동량 기록

Fig. 11. Exercise volume records 


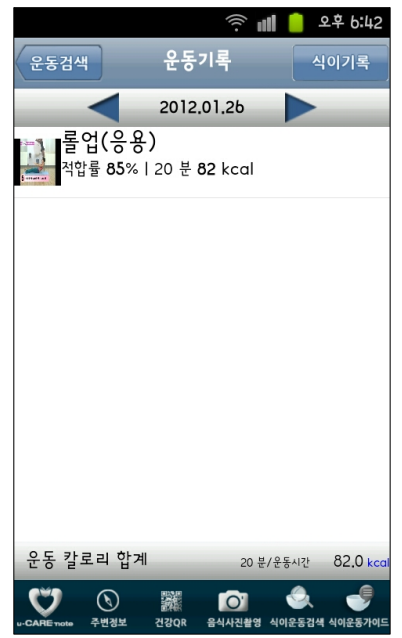

그림 12. 운동 기록

Fig. 12. Exercise Records

\subsection{GPS 기반 주변 식당 내 음식정보 제공}

지자체의 영양 표시 사업에서 제공하는 $\mathrm{DB}$ 를 기반으로 현 재 내 위치 기반으로 그림 13 과 같이 $500 \mathrm{~m}, 1 \mathrm{~km}, 3 \mathrm{~km}$, $5 \mathrm{~km}$ 반경까지의 주변 식당을 찾아볼 수 있다. 이 때 추천된 식당의 메뉴와 음식정보, 영양 분석 정보를 제공 받을 수 있 다. 식당 메뉴는 그림 14 와 같이 PHR정보를 기반으로 적합 률이 계산되어 제공된다. 음식별 영양분석 정보는 그림 15 와 같이 제공된다.

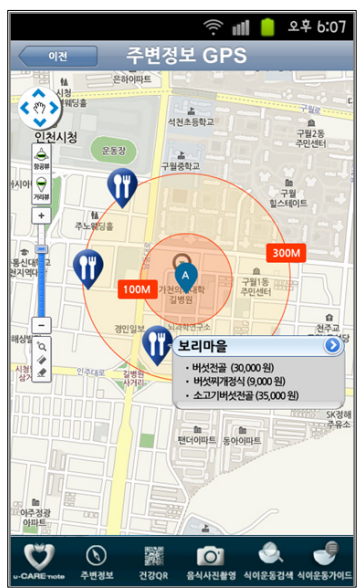

그림 13. 주변정보 GPS

Fig. 13. GPS Information

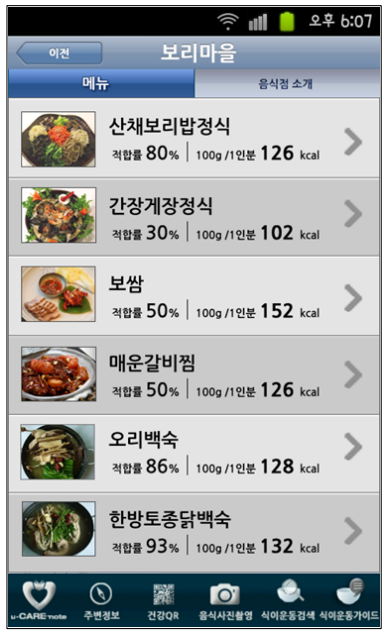

그림 14. 식당 메뉴 정보

Fig. 14. Restaurant Menu Information

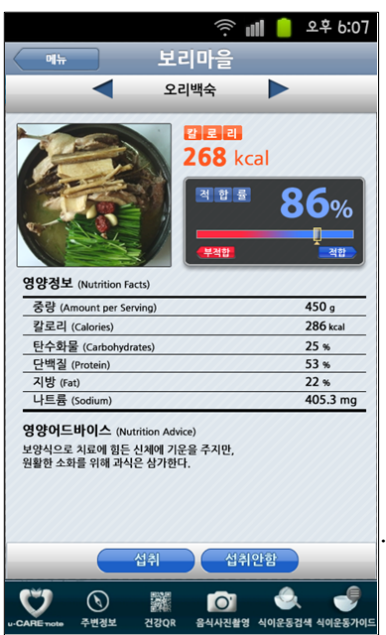

그림 15. 음식 영양 정보

Fig. 15. Food Nutrition Information

\section{V. 결론}

본 연구에서는 PHR을 기반으로 개인이 가지고 있는 질환 에 근거한 식이·운동 콘텐츠와 그 적합률을 제공하고 식이 운 동기록까지 가능한 스마트폰 어플리케이션을 개발하였다.

PHR 정보에서 11 가지의 질환 정보에 근거한 적합률 알고 리즘을 기반으로 각 식이·운동 콘텐츠에 대한 적합률을 제공 한다. 서비스 애플리케이션 사용자는 섭취한 음식의 정보를 다양한 단위로 입력하여 그 정확성을 더하고, 운동량을 기록 하여 섭취, 소비한 칼로리를 기록한다. GPS 정보를 이용한 
주변 식당 검색이 가능하며 식당 메뉴별 사용자의 질환 정보 에 따른 적합률, 영양 분석 정보가 제공된다.

사용자가 사용자의 정보를 입력하고 입력한 사항에 해당 하는 콘텐츠를 서비스 받는 것이 아니라, PHR서비스에 가입 되어 있는 경우 PHR의 의료정보에 근거한 질환 맞춤형 식이. 운동 콘텐츠를 제공하여, 기존의 사용자가 콘텐츠를 찾아가는 서비스와는 차별화 된다.

연구의 제한점으로는 현재 해당되는 질환이 없는 경우는 서비스 연동이 되지 않아 서비스가 불가하나, 해당 질환이 없 는 경우라도 질병 예방 및 건강 증진 식이·운동에 대한 콘텐 츠를 제공 받을 수 있도록 업데이트를 진행 중이다. 또한 지 자체의 영양 분석 제공 사업의 범위가 크게 확대되지 않아 식 당 및 해당 음식 정보 제공의 양에 한계가 있다. 향후 대중음 식점의 영양 표시 사업의 범위가 넓어진다면 서비스의 콘텐츠 가 더욱 많이 제공될 수 있다.

또한, SNS(Social Network Service)와 연동하여 PatientsLikeMe[40]와 같이 동일한 질병을 가진 사람들끼 리의 커뮤니티, 건강정보 공유 커뮤니티 등을 개설하여 더욱 활발하게 서비스를 활용할 수 있을 것이다. 마지막으로 기록 된 식이·운동 정보를 기반으로 사용자가 선호하는 유형 패턴 을 추출하여 더욱 맞춤화된 정보를 제공할 수 있는 서비스 시 도가 필요하며, 서비스의 효과에 대한 질환별 사용자의 피드 백, 만족도 조사와, 개선사항 및 삶의 질에 대한 추가연구를 통해 서비스 질을 높이는 연구가 필요할 것이다.

\section{참고문헌}

〔1] Jung Hoon Park, Taegkeun Whangbo,

"IT convergence Healthcare technology", korea information and communications society. Vol.28, No5, pp.21-27, April, 2011.

(2) Terry M, "Medical apps for smartphones.",

Telemed J E Health, 16(1):17-22, Jan-Feb, 2010.

(3) Sarasohn-Kahn J, "How smartphones are changing healthcare for consumers and providers", California HealthCare Foundation, April, 2010.

(4) Jong-Hun Kim, Jee-Song Park, Eun-Young Jung, Dong-Kyun Park, Young-Ho Lee,

"A Diet Prescription System for U-Healthcare Personalized Services", The Korea Contents Association Vol.10, No.2, Feb, 2009.

(5) Chan-Soon Jeong, Jun-Seok Ham, Il-Ju Ko,
Jun-Soo Hur, "Smart Exercise Prescription of Elderly Users using Visual Path Map.", Korea Society of computer information, 16(10), Oct, 2011.

(6) Welltizen, http://neps. welltizen.com/home/index.asp

(7) DreamcareTV, http://iptv.dreamcare.co.kr/

(8) Young-Ho Lee, Jong-Hun Kim,, Jae-Kwon Kim, Kyoung-Pil Min, Eun-Young Jung, Dong-Kyun Park. "Smart Phone based Personalized Menu Management System for Diabetes Patient.", The Journal of the Korea Contents Association, 10(12): 1-9, Dec, 2010.

(9) Nike Plus, http://www.nike.co.kr

(10) Adidas miCoach, http://www.adidas.com $/ \mathrm{kr} / \mathrm{miCoach}$

(11) Korea National Diabetes Program, http://itunes.apple.com/kr/app/id388616483 https://play.google.com/store/apps/details?hl= ko\&id $=\mathrm{kr}$.connect.touch.khmc

(12) Q-care, http://qcare.gg.go.kr

(13) AidHealth, http://sites.google.com/site/minolasoft/aidhealth

(14) My Medical, http://www.mymedicalapp.com/about.html

(15) Polka Health, http://itunes.apple.com/us/app/polka-health/i $\mathrm{d} 300156700 ? \mathrm{mt}=8$

(16) Britain G., "Computerisation of personal health records." Health Visit, 51: 227, 1978.

(17) HIMSS, "Personal Health Records Definition and Position Statement", 2007.

(18) http://www.himss.org/content/files/PHR-Definit ion071707.pdf.

(19) Soo-Yong Shin, Chun Kee Chung, "A Future of Medical Information System: Establishment of Hospital-oriented Personal Health Record.", J Korean Med Assoc, 52(11): 1115-1121, 2009.

(20) Lee JW, Kim SA, “comparative study on eating habits and nutrients intake of depressed and normal subjects : Base on 2008 Korean National Health and Nutrition Examination Survey", The Korean Society of Community Nutrition, 16(5), 2011.

(21) Park Kui-Sun, Lee Kyoung-Ae, "A Case Study en the Effect of $\mathrm{Ca}$ Intake on Depression and Anxiety." The Korean Nutrition Society, 35(1) : 
45-52, 2002.

(22) Benton D., "Selenium supplementation improves mood in a double-blind crossover trial.", Psychopharmacology (Berl). 102(4) : 549-550, 1990.

(23) Carroll D, Cook R, Suter M, Willemsen G, "The effect of an oral multivitamins combination with calcium, magnesium and Zinc on psychological well-being in health young male volunteers: a double-blind placebo-controlled trial."

Psychoparmacology, $150:$ 220-225, 2000.

(24) Eun-Mi Choi, Seong-Ja Gu, "Mood disorders and depression adjusting possibility by Food." Korean Society of Food Science and Technology, Vol.34, No.4, pp.53-69, ISSN 0257-2397, Dec, 2001.

(25) Harold H, Broomfield, Peter Mack Williams.. "Methods of 92 kinds for depression out of the way BOOK"

(26) Jung-Hyun kim, Mi-Young Park others 2 people. "Ecological Analysis of Food Behavior and Life-Style Affecting the Prevalence of Depression in korea, korea J Nutrition 26(9) : 1129 1137, 1993

(27) korea J Nutrition, Dietary Reference Intakes for Koreans (KDRIs) 2010.

(28) korea Dietitians Association, Manual of Medical Nutritional Therapy BOOK 3rd 2010.

(29) jong-gil Kim, “A study of depression”, 2009.

(30) jae-uk Gwak, "Nutritional therapy of depression", Pharmaceutical newspaper, 2005.

(31) Korean Association for Vitamin research, http://www. vitaminlab.co.kr

(32) Ahtoboohru. "How to treat the disease for Enhance immunity", 2006.

(33) J.R. Hibbeln, N.Salem,

"Dietary Polyunsaturated fatty acids and Depression: When Cholesterol Does Not Satisfy?," Am J Nutr 62, 1-9, July, 1995

(32) jun-nam Lee. "Supplements known to eat", Health Newspaper, 2009

(33) Sherry ribereuman. "The Peal Vitamin and Mineral BOOK 3rd Edition”, 2003
(34) yong-jin Jwa. "Vitamin Revolution", Woongjin Wings, 2006

(35) won-jun Hwang. "Mastering the treatment of depression BOOK, 2009.

(36) Sung-Kil Hong, Bong-Joo Kang. yoon-jin Kim, Dong-wook jo "Enhancement effect of brain tissue antioxidantBy administered selenium", korea J Nutrition, pp.112, 2000.

(37) gwi-seon Park.

"The Effect of calcium Supplementation and Supplementary Duration with Depression at Korean Home-Maker", pp59-68, 2003.

(38) Darren, E., "Prescribing exercise as preventive therapy.", Canadian Medical Association Journal, 174(7) : 961-974, 2006.

(39) Patients Like Me, http://www.patientslikeme.com/about 


\section{저 자 소 개}

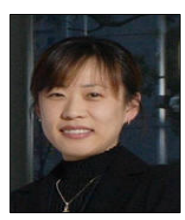

정 은 영

2002 : 가천의대 보건정보학과 석사

2012 : 아주대 의과대학 의료정보학과 이학박사

1992 현재 : 가천대 길병원 간호사

2005 2008 : 유헬스케어센터 선임연구원

2008 현재 : 유헬스케어센터 팀장

관심분야 : 의료정보학,

유헬스케어, 환자안전

Email : eyjung@gilhospital.com

정 병 희

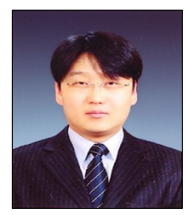

2001 : 전주대학교 생물학전공 이학사

2010 : 인천대학교 정보통신공학과 공학석사

2012 : 인천대학교 컴퓨터공학과 박사과정

현 재 : Bio Research Complex 유헬스팀 선임연구원

관심분야 : 컴퓨터공학, 유헬스

Email : buxbany@gmail.com

윤 은 실

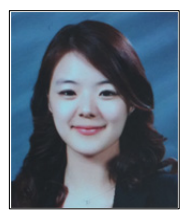

2008 : 가천의과학대학교 $\mathrm{u}$-헬스케어 연구소 연구원

2012 : 가천의과학대학교 의공학과 학사

현 재 : 서울대학교 대학원 바이오엔지 니어링전공 석사과정

관심분야 : 유헬스케어, 의료정보

Email : na1004dang@gmail.com

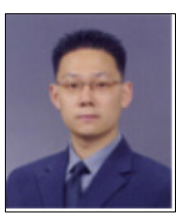

김 동 진

2002 : 상명대학교 체육학과 체육학사

2004 : 호서대학교 체육학과 스포츠의학 석사

2007 : 고려대학교 체육학과 스포츠의학 박사수료

현 재 : (주)웰티즌 기업부설연구소 책임연구원

관심분야 : 스포츠의학

Email : kemp75@welltizen.com

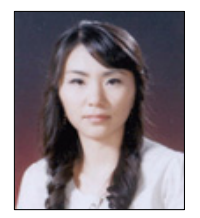

박 윤 영

2006 : 덕성여자대학교 식품영양학과 이학사

2010 : 덕성여자대학교 교육대학원 영양교육학과 교육학석사

현 재 : (주)웰티즌 기업부설연구소 선임연구원

관심분야 : 식품영양학

Emai 1: transyy@welltizen.com

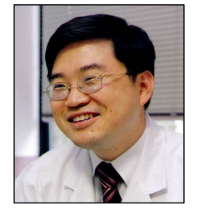

\section{박 동 균}

1992 : 충북대학교 의과대학 의학사 2003 : 인하대학교 의과대학 의학석사 2010 : 인하대학교 의과대학 의학박사 현 재 : 가천대 길병원 교수 소화기내과분과 전문의, 내시경 전문의

현 재 : 가천대 길병원 유헬스케어센터장 관심분야 : Medical Informatics, RFID/USN Application, System Medicine

Email : pdk66@gilhospital.com 